\title{
POTENSI EPIBIOTIK CAMPURAN EKSTRAK DAUN BINAHONG (Anredera cordifolia) DAN TEMULAWAK (Curcuma zanthorrhiza) PADA PAKAN UNTUK MENGATASI INFEKSI Aeromonas hydrophila PADA IKAN LELE (Clarias gariepinus)
}

\section{The Potential of Epibiotic Mixed of Binahong Leaves and Curcumin Extracts in Feed to Against Aeromonas hydrophila Infection in Catfish (Clarias gariepinus)}

\author{
Sarjito, Slamet Budi Prayitno, Nida Qolbi Salma Rochani, Alfabetian Herjuno Condro Haditomo, Rosa Amalia, Desrina \\ Departemen Akuakultur \\ Fakultas Perikanan dan Ilmu Kelautan \\ Universitas Diponegoro \\ Email: sarjito@live.undip.ac.id
}

Diserahkan tanggal 11 Maret 2020, Diterima tanggal 10 April 2020

\begin{abstract}
ABSTRAK
Salah satu permasalahan pada budidaya ikan lele adalah Aeromonasis yang disebabkan oleh Aeromonas hydrophila. Berbagai upaya pencegahan dan pengobatan telah dilakukan dengan menggunakan bahan kimia maupun herbal. Bahan herbal, berupa epibiotik (tunggal maupun campuran) digunakan oleh pembudidaya untuk pencegahan dan pengobatan penyakit ini, karena mudah diperoleh, murah dan ramah lingkungan. Penelitian ini bertujuan untuk mengkaji pengaruh penambahan campuran epibiotik, ekstrak daun binahong dan temulawak pada pakan terhadap profil darah dan kelulushidupan ikan lele yang diinfeksi A. hydrophila. Metoda yang digunakan adalah eksperimen dengan Rancangan Acak Lengkap (6 perlakuan dan 3 ulangan). Seratus delapan puluh ikan lele uji dengan panjang 7-9 cm yang dipelihara pada akuarium berisi air $10 \mathrm{~L}$. Dosis campuran epibiotik, esktrak daun binahong dan temulawak menggunakan perbandingan untuk perlakuan A (0\%:0\%), B (100\%:0\%), C (75\%:25\%), D (50\%:50\%), E (25\%:75\%) dan $\mathrm{F}(0 \%: 100 \%)$ dengan dosis dasar 2500 ppm untuk ekstrak daun binahong dan 900 ppm untuk temulawak. Campuran epibiotik tersebut ditambahkan pada pakan komersil sebagai pakan uji dengan metode spray. Pakan uji diberikan selama 14 hari, kemudian pada hari kelimabelas ikan uji diinjeksi $A$. hydrophila secara intramuscular dengan konsentrasi $10^{6} \mathrm{CFU} / \mathrm{mL}$. Hasil penelitian menunjukkan bahwa gejala klinis ikan lele yang terinfeksi $A$. hydrophila adalah nafsu makan rendah, bercak merah, luka, haemorhagi serta warna tubuh memucat. Penambahan campuran epiobiotik ekstrak daun binahong dan temulawak berpengaruh nyata $(p<0,05)$ terhadap profil darah dan kelulushidupan ikan uji pasca perlakuan dan pasca infeksi. Campuran epibiotik D mampu melawan infeksi A.hydrophilla pada $C$. gariepinus dengan tingkat kelulushidupan tertinggi $(90 \pm 17 \%)$.
\end{abstract}

Kata kunci: Aeromonas hydrophila; binahong; lele; temulawak

\section{ABSTRACT}

One of the problems in catfish culture was aeromonasis that was caused by Aeromonas hydrophila. The prevention and threatment of this disease have been carried out with using chemichal substance and an epibiotics from eco-friendly herbal plant extracts. Epibiotics, such as binahong leaves and curcuma extracts had been applicated by farmers to threat this disease because of it's cheap and easy to get it. The aims of this study was to evaluate the effect of mixture binahong leaves and curcuma extracts in feed on blood profile and survival rate of catfish infected A. hydrophila. The method of research used was Completely Randomized Design, consisted of 6 treatments and 3 replications. The catfish used was 180 fishes with length of 7-9 cm that were cultured in aquarium with $10 L$ waters. The basic dosage of binahong leaves and curcuma extracts used was 2500 ppm and 900 ppm with the ratio of treatment $A(0 \%: 0 \%), B(100 \%: 0 \%), C(75 \%: 25 \%), D(50 \%: 50 \%), E(25 \%: 75 \%)$, and $F(0 \%: 100 \%)$. The mix extract was added to the commercial feed as a feed test with spray methods. The treatment feed was given for 14 days and on the next day was done infected A. hydrophila intramusculary with density of $10^{6} \mathrm{CFU} / \mathrm{mL}$. The result showed that catfish infected A. hydrophila had low appetite, redness, ulcer, and hemorhagic, pale body. Feeding with the treatment feed showed the significant result on catfish's blood profile and survival rate post-treatments and post-infection $(p<0.05)$. Treatment $D$ showed the best result on survival rate $(90 \pm 17 \%)$.

Keywords: Aeromonas hydrophila; binahong, cat fish, curcuma

\section{PENDAHULUAN}

Produksi ikan lele di Indonesia mengalami peningkatan produksi pada tahun 2015 hingga tahun 2018, yaitu 56,32\%. Total produksi pada tahun 2018 mencapai 1,81 juta ton ikan lele (KKP, 2018). Untuk itu, penerapan budidaya ikan lele secara intensif perlu dilakukan sebagai upaya memenuhi permintaan yang terus meningkat. Namun, penerapan teknologi intensif secara kurang tepat dapat menyebabkan kualitas air yang menurun (Sarjito et al., 2019) dan meningkatkan stress pada ikan budidaya, sehingga ikan mudah terserang penyakit (Hardi et al., 2018 a). Salah satu penyakit 
yang ditemukan pada ikan lele adalah Aeromonasis yang disebabkan oleh bakteri genus Aeromonas. Selain itu, genus bakteri ini juga dapat menyebabkan penyakit (MAS) pada ikan yang ditandai adanya kematian massal sampai $80-100 \%$ dalam waktu 1-2 minggu, dengan septicemia pada tubuhnya, sehingga mengakibatkan kerugian ekonomi yang tinggi (Muslikha et al., 2016, Agustina et al., 2019)

Berbagai upaya telah dilakukan untuk mengatasi penyakit bakteri pada ikan dengan menggunakan obat-obatan kimia dan herbal. Pemakaian bahan herbal (epibiotik) berupa ekstrak tumbuhan herbal semakin banyak digunakan,karena ramah lingkungan, mudah terurai dan tidak menimbulkan efek resisten terhadap ikan, sehingga cocok digunakan untuk akuakultur berkelanjutan (Hardi et al., 2017). Aplikasi pencegahan penyakit dengan ekstrak bahan herbal dapat dilakukan dengan cara injeksi, melalui media budidaya atau penambahan dalam pakan. Penambahan ekstrak dalam pakan dinilai lebih praktis dalam hal pembuatan dan pemberiannya pada ikan lele dibandingkan dengan cara injeksi atau penyuntikan terutama dalam budidaya skala massal (Wahjuningrum et al., 2013).

Beberapa penelitian menunjukkan bahwa penambahan ekstrak daun binahong 2500 ppm pada pakan dapat mempercepat proses penyembuhan ikan lele yang terinfeksi $A$. caviae (Basyuni et al., 2017). Ekstrak daun binahong dapat menghambat pertumbuhan bakteri $A$. hydrophila karena menggandung flavonoid yang berfungsi sebagai antibiotik, fenolik yang dapat menyebabkan denaturasi protein dan kerusakan sel, serta saponin dan alkaloid yang berfungsi sebagai antimikroba dan antibakteri. Demikian pula ekstrak temulawak yang ditambahkan pada pakan sebanyak $900 \mathrm{ppm}$ berpengaruh terhadap nilai kelulushidupan ikan hingga 97,83\% pada ikan yang terinfeksi bakteri. Ekstrak temulawak diketahui mengandung kurkumin sebagai zat antimikroba Dyang dapat menghambat pertumbuhan dan mematikan mikroorganisme seperti bakteri Escherichia coli, Bacillus cereus, Salmonella thypi, dan Aeromonas hydrophila (Putra et al., 2015). Oleh karena itu, penambahan ekstrak tunggal dan binahong dan temulawak secara tunggal mampu mencegah infeksi bakteri. Pemberian kombinasi ekstrak daun binahong dan temulawak diduga lebih efektif untuk mencegah infeksi bakteri dibandingkan ekstrak tunggal. Oleh karena itu, perlu dikaji potensi campuran ekstrak daun binahong dan temulawak dalam pakan terhadap profil darah dan kelulushidupan ikan lele yang diinfeksi bakteri $A$. hydrophila serta untuk mengetahui dosis campuran terbaik dalam pakan untuk mencegah infeksi bakteri pathogen ini pada ikan lele. Penelitian ini dilaksanakan pada bulan April - September 2019 di Laboratorium Departemen Akuakultur, Fakultas Perikanan dan Ilmu Kelautan, Universitas Diponegoro, Semarang.

\section{METODE PENELITIAN}

Ikan uji yang digunakan dalam penelitian ini adalah benih ikan lele yang berasal dari pembudidaya ikan di Kampung Lele, Boyolali dengan ukuran panjang 7-9 cm sebanyak 180 ekor. Wadah uji adalah akuarium (ukuran $40 \mathrm{x}$ $30 \times 30 \mathrm{~cm}^{3}$ ) yang dilengkapi dengan sistem aerasi. Isolat murni bakteri $A$. hydrophila diperoleh dari Badan Karantina Ikan dan Pengendalian Mutu (BKIPM) Yogyakarta. Media kultur bakteri yang digunakan adalah TSA (Trypticase Soy Agar) dan GSP (Glutamate Stratch Phenile) sebagai media padat serta TSB (Trypticase Soy Broth) sebagai media cair.
Bahan uji yang digunakan ialah ekstrak daun binahong dan temulawak diperoleh dari kabupaten Semarang.

Metode penelitian yang digunakan yaitu metode eksperimental dengan rancangan acak lengkap (6 perlakuan dan 3 ulangan). Konsentrasi dasar ekstrak daun binahong dan temulawak yang digunakan adalah $2500 \mathrm{ppm}$ (Dadiono et al., 2017) dan 900 ppm (Putra et al., 2015). Perlakuan yang digunakan adalah kombinasi ekstrak daun binahong dan temulawak yang dicampurkan dalam pakan dengan perbandingan 0\%:0\% (perlakuan A), 100\%:0\% (perlakuan B), 75\%:25\% (perlakuan C), 50\%:50\% (perlakuan D), 25\%:75\% (perlakuan E) dan 0\%:100\% (perlakuan F).

Metode kultur bakteri ini mengacu pada metode Sarjito (2010). Inokulasi isolat murni $A$. hydrophila dari media TSA miring ke dalam media cair TSB, kemudian dihomogenkan dengan menggunakan vortex dan diinkubasi selama 24 jam pada water bath shaker. Kemudian bakteri dipanen dengan mensetrifuge, sehingga dapat diperoleh supernatant. Supernatan dicuci dengan PBS tiga kali, maka diperoleh konsentrat bakteri. Konsentrat bakteri tersebut kemudian dilarutkan dengan aguabides, kemudian kadar bakteri diukur dengan spectrophotometer. Satu $\mathrm{ml}$ konsentrat bakteri, kemudian diencerkan menggunakan aquabides sebanyak sembilan $\mathrm{ml}$, begitu seterusnya. Pengenceran dilakukan hingga dicapai kepadatan bakteri $10^{6} \mathrm{CFU} / \mathrm{mL}$. Untuk meningkatkan virulensi bakteri, maka pada penelitian ini dilakukan pasase sebanyak tiga kali. Pasase dilakukan dengan menginjeksikan sebanyak $0,1 \mathrm{ml}$ dengan kepadatan $10^{6} \mathrm{CFU} / \mathrm{mL}$ pada bagian intramuscular pada lima ekor ikan uji. Selanjutnya, kelima ekor ikan tersebut diamati selama tiga hari, jika ikan belum menunjukkan gejala klinis, maka dilakukan isolasi dari ginjal dan luka dengan media GSP. Koloni bakteri $A$. hydrophila yang tumbuh pada media GSP, kemudian dikultur pada media TSA untuk memperoleh isolat murni dari bakteri tersebut. Selanjutnya, bakteri dikultur kembali pada media TSB, setelah 24 jam dilakukan proses pasase kembali ke ikan hingga ikan menunjukkan gejala klinis terserang $A$. hydrophila.

Pembuatan ekstrak daun binahong ( $A$. cordifolia) dan temulawak mengacu pada metoda dari Miladiyah dan Prabowo (2012) dan Sari et al. (2012). Daun binahong dan temulawak dibersihkan dengan air bersih, kemudian ditiriskan dan dikeringkan. Sebelum dikeringkan, temulawak diiris tipis-tipis terlebih dahulu. Daun binahong dan temulawak yang telah kering, masing-masing dihaluskan dan ditimbang. Selanjutnya, dilakukan proses maserasi untuk memperoleh ekstrak. Maserasi dilakukan dengan mencampurkan bahan - bahan tersebut dengan etanol 96\% dalam Erlenmeyer memakai perbandingan 1:5 untuk daun binahong dan 1:3 untuk temulawak, kemudian didiamkan selama 24 jam. Selanjutnya, larutan disaring menggunakan kertas saring untuk memperoleh larutan ekstrak (Sakti et al., 2019). Larutan ekstrak kemudian dievaporasi dengan menggunakan rotary evaporator untuk memisahkan ekstrak dengan pelarutnya pada suhu $50^{\circ} \mathrm{C}$ dengan kecepatan 120 rpm, sehingga diperoleh ekstrak tanpa pelarut yang berbentuk pasta (Susanti dan Bachmid, 2016). Ekstrak berupa pasta tersebut kemudian diencerkan menggunakan aquades sesuai dengan konsentrasi perlakuan. Selanjutnya, ekstrak disemprotkan pada pakan komersil dan diberi label pada masing-masing perlakuan. Pakan uji kemudian dianginanginkan hingga kering agar tidak berjamur.

Ikan uji yang digunakan adalah ikan yang sehat, yaitu berenang normal dan tidak cacat. Setiap akuarium berisi ikan uji sebanyak 10 ekor. Ikan diberi pakan uji sebanyak 3\% bobot

\footnotetext{
(C) Copyright by Saintek Perikanan: Indonesian Journal of Fisheries Science and Technology, ISSN : 1858-4748
} 
biomassa per hari sebanyak 3 kali yaitu pukul 08.00, 14.00 dan 20.00 WIB. Pakan uji diberikan selama 14 hari dan kemudian dilakukan infeksi bakteri $A$. hydrophila sebanyak $0,1 \mathrm{ml}$ secara intramuscular dengan kepadatan $10^{6} \mathrm{CFU} / \mathrm{mL}$. Hari ke-15 hingga hari ke-21 ikan diberi pakan komersil tanpa penambahan ekstrak.

Parameter yang diamati meliputi gejala klinis, total leukosit, total eritrosit, hematokrit dan hemoglobin, tingkat kelulushidupan dan kualitas air. Pengamatan gejala klinis dilakukan setiap hari setelah dilakukan uji tantang. Gejala klinis diamati secara visual meliputi respon pakan dan morfologi ikan. Sedangkan pengukuran profil darah (total leukosit, total eritrosit, hematokrit dan hemoglobin) dilakukan sebanyak 4 kali selama penelitian, yaitu sebelum diberi pakan uji (hari ke-0), setelah diberi pakan uji (hari ke-13), 1 hari setelah infeksi bakteri $A$. hydrophila (hari ke-15) dan 7 hari setelah infeksi bakteri $A$. hydrophila (hari ke-21). Parameter kualitas air yang diukur, meliputi kadar oksigen terlarut (DO), tingkat keasaman air $(\mathrm{pH})$ dan temperature dilakukan setiap tujuh hari sekali.

Data berupa total leukosit, total eritrosit, hematokrit, hemoglobin, dan kelulushidupan dianalisis dengan analisis ragam (ANOVA) dengan menggunakan SPSS versi 24.0. Sedangkan gejala klinis dan kualitas air (DO, $\mathrm{pH}$ dan suhu) dianalisis secara deskriptif.

\section{HASIL DAN PEMBAHASAN}

\section{Hasil}

\section{Gejala Klinis}

Gejala klinis yang ditunjukkan ikan lele setelah dilakukan infeksi bakteri A. hydrophila berupa perubahan tingkah laku dan morfologi ikan. Perubahan morfologi ikan lele setelah diinfeksi bakteri $A$. hydrophila adalah bercak merah (Gambar 1a), luka (Gambar 1b), dan hemoragi (Gambar 1c). Gejala klinis tersebut mulai terdeteksi sehari pasca infeksi .yaitu pada hari ke-16 sampai dengan hari ke-21 perlakuan A, sedangkan untuk perlakuan lainnya terlihat pada hari ke-16 sampai dengan hari ke-20. Selain itu, perubahan tingkah laku juga terlihat yaitu ikan berenang pasif dan respon ikan terhadap pakan lambat. Ikan berenang pasif terlihat pada hari ke-15 (pasca infeksi) dan sebagian terlihat meggerombol di dasar akuarium pada hari ke-16 hingga hari ke-18. Ikan terdeteksi mulai berenang aktif kembali pada hari ke-19 pada perlakuan $\mathrm{D}$ dan hari ke-20 pada perlakuan B, C, E, dan F. Sedangkan pada perlakuan A ikan berenang pasif hingga hari ke-21. Perubahan respon ikan terhadap pakan juga berubah setelah dilakukan infeksi $A$. hydrophila. Selain itu, pada hari ke-15 ikan cenderung lambat dalam merespon pakan hingga hari ke17, akan tetapi mulai hari ke-9 respon ikan terhadap pakan berangsur -angsur kembali normal.mulai hari ke-19.

\section{Profil Darah}

Hasil pengamatan profil darah (total eritrosit, total leukosit, hematokrit, dan hemoglobin) pada hari ke-0, hari ke13 setelah pemberian pakan uji, hari ke-15 (1 hari setelah diinfeksi $A$. hydrophila) dan hari ke-21 (7 hari setelah dinfeksi A. hydrophila), tersaji pada Gambar 2.

Gambar 2. Memperlihatkan bahwa rerata total leukosit mengalami peningkatan pada hari ke-13 dan hari ke15, sedangkan rerata total eritrosit, hematokrit dan hemoglobin mengalami penurunan. Hari ke-21 menunjukkan adanya penurunan total leukosit dan peningkatan rerata total eritrosit, hematokrit dan hemoglobin dibandingkan hari ke-15. Hasil analisis ragam menunjukkan bahwa penambahan epibiotik campuran ekstrak daun binahong dan curcumin dengan prosentase yang berbeda pada pakan selama 13 hari berpengaruh nyata $(P<0,05)$ terhadap total leukosit, total eritrosit dan hemoglobin, namun tidak berpengaruh nyata $(p>0,05)$ terhadap hematokrit. Hasil yang sama juga ditunjukkan pada profil darah ikan uji pasca infeksi (hari ke-15 dan hari ke-21) yaitu pemberian epiobiotik campuran ini berpengaruh nyata $(P<0,05)$ terhadap keempat parameter profil darah.

\section{Kelulushidupan}

Kelulushidupan ikan lele yang diberi pakan dengan penambahan kombinasi campuran ekstrak daun binahong dan temulawak serta diinfeksi bakteri $A$. hydrophila tersaji pada Gambar 3.

Gambar 3. menunjukkan bahwa pemberian kombinasi campuran epibiotik yang berbeda pada pakan memberikan pengaruh nyata terhadap kelulushidupan ikan lele $(p<0,05)$. Gambar 3 juga memperlihatkan bahwa kelulushidupan tertinggi ditemukan pada perlakuan D $(90 \pm 17 \%)$ dan terendah pada perlakuan A $(43 \pm 15 \%)$.

\section{Kualitas Air}

Kualitas air selama penelitian (Tabel 1.) adalah layak untuk pemeliharaan lele.

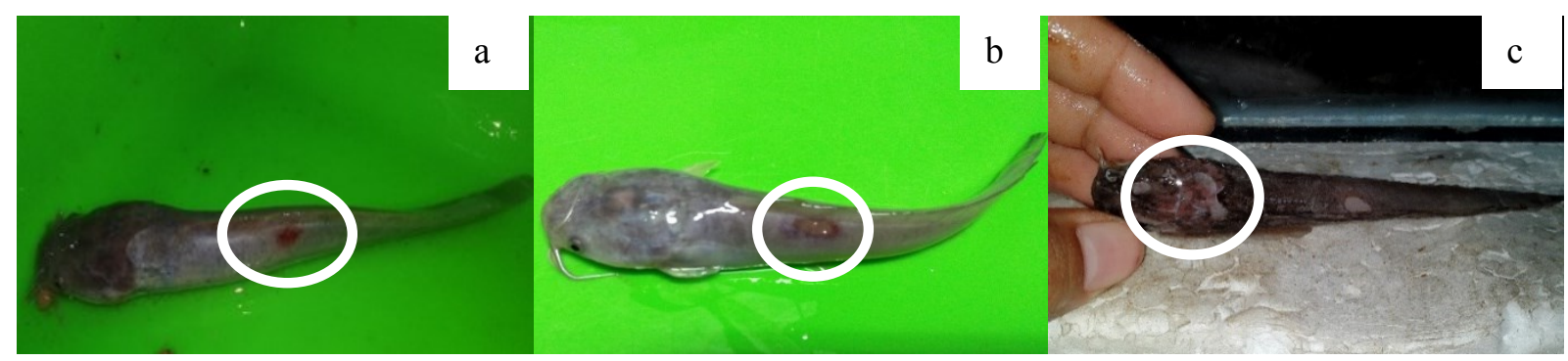

Gambar 1. Gejala Klinis Ikan Lele Setelah Infeksi Bakteri A. hydrophila

a) bercak Merah, b) Luka/Ulcer; c) Hemorhagi 


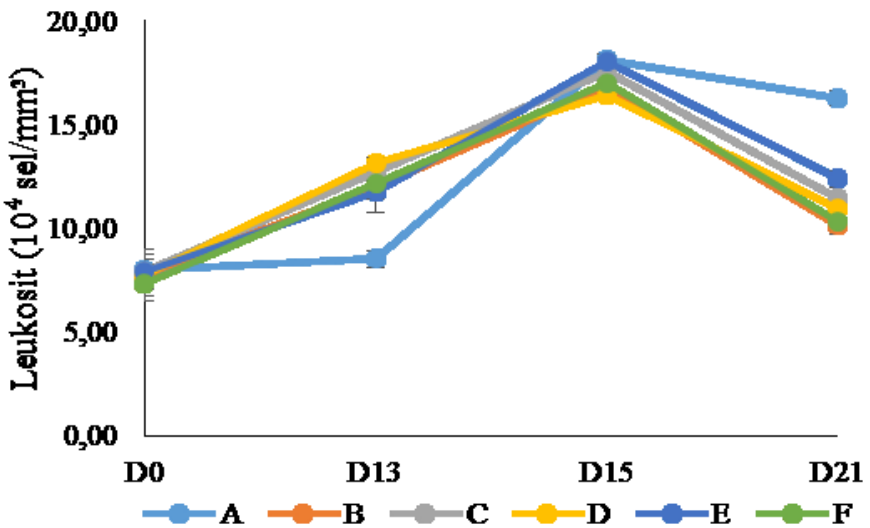

(a)

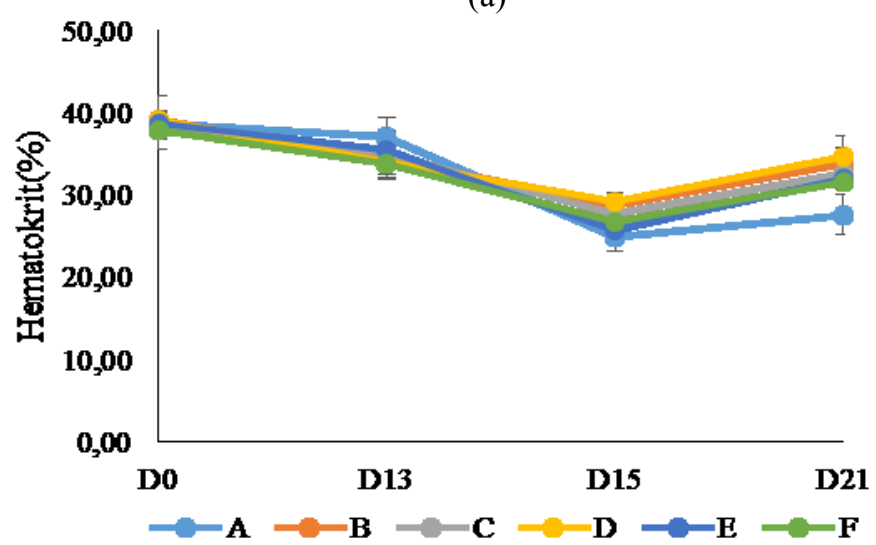

(c)

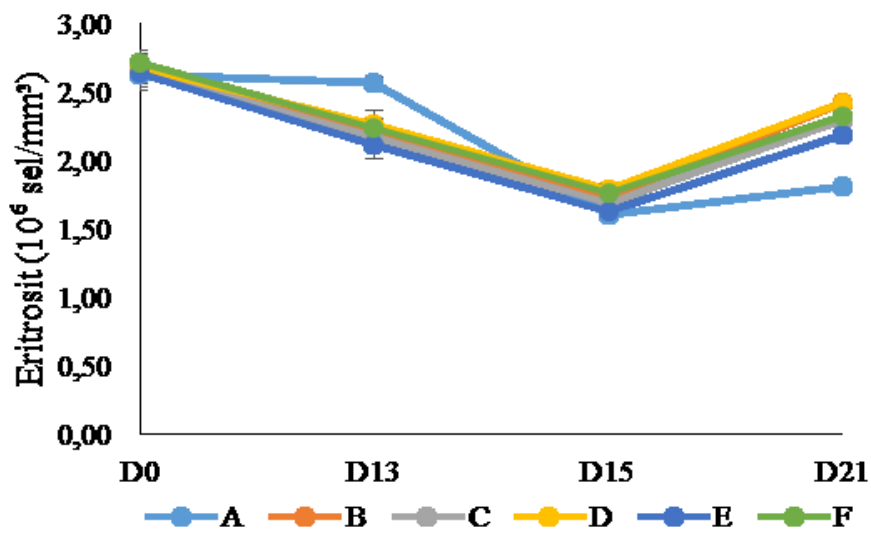

(b)

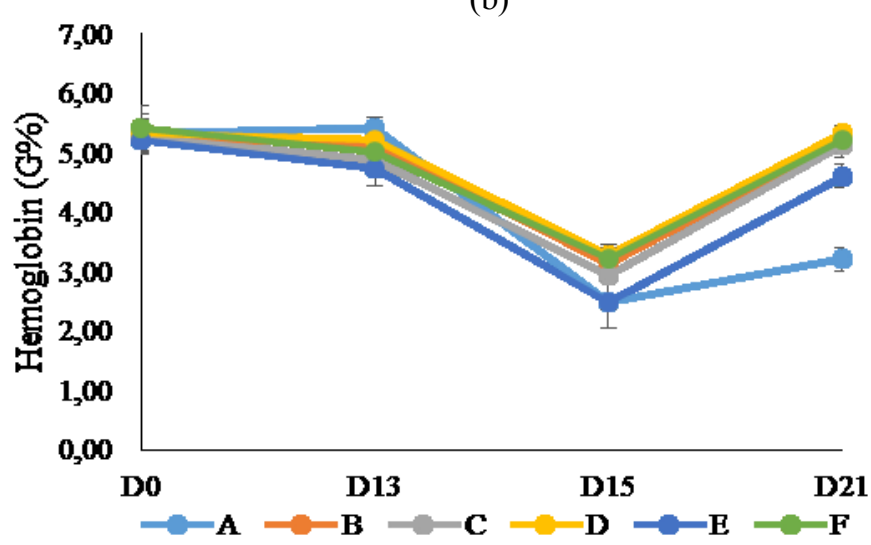

(d)

Gambar 2. Grafik Profil Darah Ikan Lele Selama Penelitian (a)Total Leukosit; (b) Total Eritrosit; (c) Hematokrit; (d) Hemoglobin

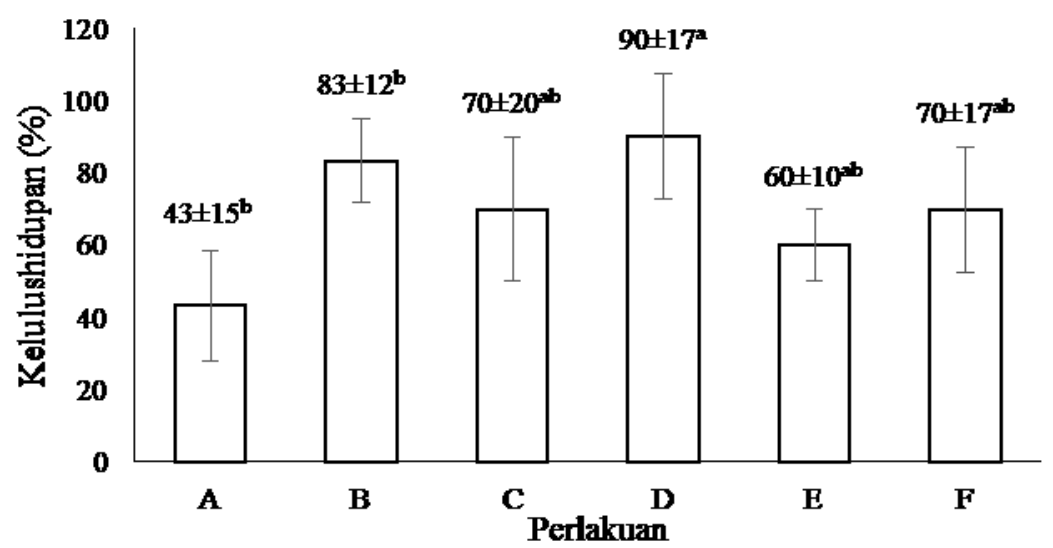

Gambar 3. Tabel Tingkat Kelulushidupan Ikan Lele

Tabel 1. Nilai Kualitas Air pada Media Pemeliharaan Ikan Lele selama Penelitian

\begin{tabular}{|c|c|c|c|c|c|c|c|}
\hline \multirow{2}{*}{ Parameter } & \multicolumn{6}{|c|}{ Perlakuan } & \multirow{2}{*}{$\begin{array}{c}\text { Kisaran } \\
\text { Optimum }\end{array}$} \\
\hline & A & B & $\mathrm{C}$ & $\mathrm{D}$ & E & F & \\
\hline $\mathrm{DO}(\mathrm{mg} / \mathrm{L})$ & $3,09-3,39$ & $3,12-3,41$ & $3,07-3,28$ & $3,14-3,50$ & $3,10-3,33$ & $3,05-3,36$ & $\geq 3^{\text {a) }}$ \\
\hline Suhu $\left({ }^{\circ} \mathrm{C}\right)$ & $26-28$ & $26-28$ & $26-28$ & $26-28$ & $26-28$ & $26-28$ & $25-32^{\text {a) }}$ \\
\hline $\mathrm{pH}$ & $7-8$ & $7-8$ & $7-8$ & $7-8$ & $7-8$ & $7-8$ & $6,5-8^{\text {a) }}$ \\
\hline
\end{tabular}

Keterangan: a) Badan Standardisasi Nasional, 2014

\section{Pembahasan}

Gejala klinis berupa bercak merah Gambar 1a) terlihat mulai hari ke-1 pasca infeksi pada semua perlakuan, sedangkan luka/borok (Gambar 1b) terdeteksi pada hari ke-2 hingga hari ke-3 pasca infeksi, dan haemorhagi (Gambar 1c) pada hari ke4 hingga hari ke-7 pasca infeksi serta warna pucat pada tubuh ikan. Gejala klinis tersebut pernah dilaporkan oleh Allah et al. (2019), Kusdarwati et al. (2018) dan Asniatih et al. (2013). Hardi et al. $\left(2018^{\mathrm{b}}\right)$ juga menjelaskan bahwa pada ikan lele yang terifeksi $A$. hydrophila, itemukan adanya lesi pada kulit, perubahan warna pada tubuh, hemorhagi dan borok. Timbulnya luka pada tubuh ikan lele ini diduga berkaitan dengan enzim

\footnotetext{
C Copyright by Saintek Perikanan: Indonesian Journal of Fisheries Science and Technology, ISSN : 1858-4748
} 
protease dari bakteri Aeromonas sp. yang dapat mendegradasi protein kompleks jaringan tubuh. Aktivitas proteolitik tersebut yang menyebabkan terjadinya lesi pada tubuh inang (Anyanwu et al., 2015).

Pada perlakuan B, C, D, E, dan F, luka juga terlihat pada hari ke-2 hingga hari ke-5 pasca infeksi. Selanjutnya pada hari ke-6, ikan pada perlakuan B, C, D, E, dan F sudah terlihat proses penyembuhan luka. Hal tersebut diduga berkaitan dengan peran bioaktif dari kombinasi campuran epibiotik ektraks daun binahong dan temulawak yang mampu menstimulasi pemulihan dari luka pada ikan. Hal ini menunjukkan bahwa penambahan kombinasi ekstrak daun binahong dan temulawak pada pakan mampu menghambat dan mematikan bakteri, sehingga ikan mampu memulihkan diri.

Perubahan tingkah laku yang ditunjukkan oleh ikan uji setelah dilakukan infeksi, yaitu ikan berenang pasif dan respon terhadap pakan lambat dan bergerombol di dasar akuarium. Gejala klinis ini juga pernah dilaporkan oleh Allah et al. (2019) dan Naibaho et al. (2018) pada ikan lele yang terserang penyakit motile aeromonas septisemia. Perubahan tingkah laku berupa penurunan nafsu makan dan renang secara lambat merupakan indikasi adanya gangguan metabolisme ikan yang diakibatkan adanya infeksi dari bakteri $A$. hydrophila (Hardi et al., 2018 ). Hasil penelitian ini juga menunjukkan bahwa tingkah laku ikan kembali berangsur angsur ke arah normal sampai hari ke-6 pasca infeksi dilakukan. Hal ini berkaitan dengan kemampuan adaptasi dan meningkatnya system immune, sehingga ikan akan menjadi normal kembali.

Nilai rerata total leukosit ikan ikan lele selama penelitian berkisar antara 7,34-7,99 × $10^{4} \mathrm{sel} / \mathrm{mm}^{3}$ pada awal penelitian (hari ke-0), 8,49-13,11 x $10^{4} \mathrm{sel} / \mathrm{mm}^{3}$ pasca pemberian pakan uji (hari ke-13), dan 16,44-18,09 x $10^{4}$ $\mathrm{sel} / \mathrm{mm}^{3}$ satu hari pasca infeksi bakteri $A$. hydrophila (hari ke15). Hasil pengukuran pada hari ke-0 dan hari ke-13 (Gambar 2a) menunjukkan total leukosit masih dalam kisaran normal, tetapi pada hari ke-15 total leukosit mengalami peningkatan hingga melewati batas normal. Menurut Riauwaty et al. (2019), ikan yang sehat memiliki total leukosit 20.000-150.000 $\mathrm{sel} / \mathrm{mm}^{3}$. Peningkatan total leukoist pada hari ke-15 disebabkan karena ekstrak daun binahong dan temulawak mengandung bahan aktif, seperti fenol, flavonoid, terpenoid, saponin, alkanoid dan coumarin yang berperan sebagai imunostimulator sehingga memacu sistem imun untuk meningkatkan pertahanan tubuh ikan terhadap antigen dengan menginduksi perbanyakan leukosit (Basyuni et al., 2017; Mawardi et al., 2019; Rosmawaty et al., 2016). Produksi leukosit ikan lele kembali meningkat pada hari ke-15 dikarenakan adanya infeksi dari bakteri $A$. hydrophila. Produksi leukosit akan meningkat ketika terjadi infeksi, dan sel-sel tersebut akan diarahkan menuju lokasi infeksi melalui pembuluh darah untuk menghambat dan melawan antigen yang masuk dalam tubuh. Leukosit juga berfungsi sebagai imun non-spesifik pada ikan dan menghambat infeksi bakteri patogen melalui fagositosis (Putra et al., 2015; Rosidah et al., 2018), sehingga leukosit berperan penting dalam sistem imun ikan (Dageubun dan Metungun, 2017)

Total leukosit pada pengukuran hari ke-21 (tujuh hari pasca infeksi) mengalami penurunan dibandingkan hari ke-15 (satu hari pasca infeksi). Rerata total leukosit pada perlakuan A masih di atas nilai normal $\left(16,27 \times 10^{4} \mathrm{sel} / \mathrm{mm}^{3}\right)$, sedangkan pada perlakuan lainnya sudah kembali normal $(10,12-12,35 \mathrm{x}$
$10^{4} \mathrm{sel} / \mathrm{mm}^{3}$ ). Hasil penelitian ini juga menunjukkan bahwa pemberian campuran ekkstrak daung binanhong dan temulawak pada pakan mampu meningkatkan sistem imun tubuh dan mempersingkat kerja waktu imun dalam melawan antigen yang masuk. Menurut Rustikawati et al., (2011) dan Rosmawaty et al. (2016), imunostimulan akan dapat meningkatkan leukosit terutama limfosit $\mathrm{T}$ untuk memproteksi tubuh dari bakteri dan virus intraseluler dan limfosit B untuk meningkatkan imunitas humoral dan serum antibodi yang berfungsi untuk menetralkan endotoksin maupun eksotoksin (Rustikawati et al., 2011; Hardi et al.,2018 a). Sehingga pemberian imunostimulan dapat meningkatkan sistem pertahanan tubuh terhadap bakteri dan menurunkan waktu yang diperlukan untuk memperbanyak antibodi.

Hasil pengukuran leukosit berbanding terbalik dengan nilai eritrosit, hematokrit dan hemoglobin ikan. Eritrosit, hematokrit dan hemoglobin mengalami penurunan pada hari ke-13 dari hari ke-0 (Gambar 2a, 2b dan 2c), namun masih dalam kisaran normal. Nilai rerata total eritrosit, hematokrit dan hemoglobin pada hari ke-13 berturut-turut, 2,12-2,57 x $10^{6}$ $\mathrm{sel} / \mathrm{mm}^{3}, 34,04-37,14 \%$, dan 2,47-3,27 g\% dan untuk kisaran normal ketiga parameter tersebut adalah 1,5-2,9 x $10^{6} \mathrm{sel} / \mathrm{mm}^{3}$ (Tiamiyu et al., 2019), 30,8-45,5\% (Rahmaningsih et al., 2018) dan 4,2-8,4 g\% (Akinrotimi et al., 2011). Kemudian, pada hari ke-15 mengalami penurunan kembali dari hari ke-13, disebabkan adanya infeksi bakteri A. hydrophila. Bakteri ini mengeluarkan hemolysin yang dapat melisiskan eritrosit dan membebaskan hemoglobin darah sehingga terjadi penurunan total eritrosit dan hemoglobin pada hari tersebut (Sarjito et al., 2019). A. hydrophila mengeluarkan enzim-enzim yang bersifat toksik seperti hemolisin yang larut dalam darah, sehingga melisis eritrosit dan membebaskan hemoglobin sehingga darah banyak keluar dan menyebabkan hemoragi. Selanjutnya, penurunan jumlah eritrosit dapat juga diakibatkan oleh aktivitas hemolitik dari bakteri (Anyanwu et al., 2015; Chah et al, 2015). A. hydrophila juga menghasilkan enzim aerolysin dan haemolysin. Enzim tersebut dapat menyebabkan sel darah membengkak dan kemudian proses kematian pada sel darah merah (Chandrarathna et al., 2018; Hardi et al., 2018 ${ }^{\text {, }}$ Muslikha et al., 2016)). Selanjutnya, pembengkakan eritrosit akan menganggu mobilisasi hemoglobin dari limpa ke organ hematopoietic lainnya sehingga mengakibatkan nilai hemoglobin menurun (Allah et al., 2019). Walaupun demikian, hasil pengukuran eritrosit selama penelitian menunjukkan bahwa total eritrosit masih dalam keadaan normal. Nilai eritrosit masih dalam keadaan normal pada ikan yang terinfeksi menunjukkan bahwa sistem imun tubuh ikan memproduksi eritrosit lebih banyak untuk menggantikan lisis eritrosit akibat infeksi bakteri (Dageubun dan Metungun 2017). Hasil analisis ragam juga menunjukkan bahwa penambahan epibiotik campuran ekstrak daun binahong dan curcumin dengan prosentase yang berbeda pada pakan selama 13 hari berpengaruh nyata $(P<0,05)$ terhadap total leukosit, total eritrosit dan hemoglobin, namun tidak berpengaruh nyata $(p>0,05)$ terhadap hematocrit $(p>0,05)$. Hasil yang sama juga ditunjukkan pada profil darah ikan uji pasca infeksi (hari ke-15 dan hari ke-21) yaitu pemberian epiobiotik campuran ini berpengaruh nyata $(\mathrm{P}<0,05)$ terhadap keempat parameter profil darah.

Penurunan hematokrit terjadi seiring dengan menurunnya jumlah eritrosit dalam darah (Saparuddin., 2018). 
Nilai hematokrit darah dipengaruhi oleh beberapa faktor seperti eritrosit (jumlah, ukuran dan bentuk), lingkungan, jenis kelamin, spesies dan stadia ikan (Setiyowati et al., 2019). Ikan yang terinfeksi akan menjadi lemah dan tidak nafsu makan sehingga laju metabolisme tubuhnya menurun dan energi yang dihasilkan rendah disebabkan oleh kadar hemoglobin yang rendah (Lusiastuti dan Hardi, 2018).

Hasil penelitian menunjukkan bahwa pemberian kombinasi campuran epibiotik yang berbeda pada pakan memberikan pengaruh nyata terhadap kelulushidupan ikan lele $(p<0,05)$. Kelulushidupan tertinggi ditunjukan oleh perlakuan D $(90 \pm 17 \%)$, diikuti oleh perlakuan B $(83 \pm 12 \%)$, perlakuan C $(70 \pm 20 \%)$, perlakuan F $(70 \pm 17 \%)$, perlakuan E $(60 \pm 10 \%)$ dan kelulushidupan terendah pada perlakuan A, yaitu $43 \pm 15 \%$. Nilai tersebut menunjukkan adanya perbedaan nyata antara perlakuan A dengan perlakuan B dan D. Perbedaan tersebut dikarenakan pada perlakuan B dan perlakuan D diberi pakan uji dengan penambahan ekstrak daun binahong dan temulawak sehingga zat aktif (fenol, flavonoid, terpenoid, saponin dan alkanoid) yang terkandung dalam ekstrak berkerja membantu tubuh melawan antigen. Bahan aktif seperti kurkumin, minyak atsiri, saponin dan flavonoid yang berfungsi sebagai antibakteri dengan cara mendenaturasi protein dan merusak membran sel bakteri (Dadiono et al. 2017; Hardi et al 2018 ${ }^{\mathrm{a}}$ ). Anti-bakteri bekerja dengan cara menghambat sintesis dinding sel, menghambat permeabilitas dinding sel bakteri, menghambat sintesis protein sel bakteri, menghambat sintesis asam nukleat sel bakteri, dan menghambat metabolisme sel bakteri (Hardi et al., 2017; Sakti et al., 2019; Wulansari et al., 2019). Nilai kelulushidupan ikan terendah terjadi pada perlakuan A, diduga karena tidak adanya tambahan imunostimulan pada pakan uji dan juga dapat diakibatkan oleh perubahan morfologi ikan pada perlakuan A, yaitu hemoragi yang tidak ditemukan pada perlakuan B, C, D, E dan F. Oleh karena itu, tingginya kematian tersebut berkaitan dengan adanya perubahan homeostasis pada tubuh ikan karena kerusakan kulit ikan akibat infeksi Aeromonas sp. dimana lesi sebesar $10 \%$ permukaan tubuh dapat menyebabkan kematian hingga 50\% (Anyanwu et al., 2015). Hasil penelitian juga diperoleh bahwa kombinasi ekstrak daun binahong dan temulawak mampu meningkatkan secara signifikan kelulushidupan ikan lele. Kombinsai campuran epibiotik pada perlakuan D menghasilkan kelulushidupan yang tertinggi $(90 \pm$ $0,17 \%)$

Hasil pengukuran kualitas air yang dilakukan setiap minggu yaitu 3,05-3,50 mg/L untuk oksigen terlarut (DO), 26 $28^{\circ} \mathrm{C}$ untuk suhu, dan 7-8 untuk pH. Hasil pengukuran kualitas air selama penelitian ini masih dalam kisaran optimum untuk ikan lele (Badan Standardisasi Nasional, 2014) maupun untuk A. hydrophila (Ardy et al., 2019).

\section{KESIMPULAN}

Penambahan epibotik campuran ekstrak daun binahong dan ekstrak temulawak pada pakan dapat mempercepat proses pemulihan ikan lele., C. gariepinus, yang terinfeksi $A$. hydrophila. Pakan uji juga memberikan pengaruh nyata $(p<0.05)$ terhadap total leukosit, total eritrosit dan hematokrit pasca perlakuan (hari ke-13) dan pasca infeksi (hari ke-15 dan ke-21), dan hematokrit ikan lele pasca infeksi (hari ke-13 dan ke-15) serta tingkat kelulushidupan ikan lele $(C$. gariepinus). Campuran epibiotik terbaik untuk mengatasi infeksi $A$. hydrophila pada $C$. gariepinus adalah 50\% ekstrak daun binahong dan 50\% ekstrak temulawak dengan tingkat kelulushidupan mencapai $90 \pm 17 \%$.

\section{UCAPAN TERIMA KASIH}

Penelitian ini didanai sepenuhnya dari Hibah Penelitian Fakultas Perikanan dan Ilmu Kelautan Universitas Diponegoro No. 11/UN7.5.10/PP/2019. Untuk itu disampaikan kepada Dekan Fakutas Perikanan dan Ilmu Kelautan Universitas Diponegoro, Ketua Laboratorium Terpadu dan Departemen Akuakultur yang telah memfasilitasi penelitian ini.

\section{DAFTAR PUSTAKA}

Agustina, P., Sarjito dan A. H. C. Haditomo. 2019. Study of Bacillus methylotrophicus as a Probiotic Candidate Bacteria With Different Concentration Against Aeromonas hydrophila on Water as a Cultivation Media of Tilapia (Oreochromis niloticus). IOP Conf. Series: Earth and Environmental Science, 246: 1-13 https://doi.org/10.1088/1755-1315/246/1/012030

Akinrotimi, O.A., D.O. Bekibele dan O.O. Orokotan. 2011. Select Hematological Values of the African Catfish (Clarias gariepinus) Raised in a Water Recirculating Aquaculture System. International Journal of Recirculating. $\quad$ Aquaculture. 12: 1-12. DOI: http://doi.org/10.21061/ijra.v12i1.1351

Abd Allah, QA., S.M. Aly, H.G.A. El-Rahman, F.M.A. Youssef dan F.K. Ahmed. 2019. Effect of some Immunostimulants on Clinicopathological Findings of African Catfish Clarias gariepinus Infected with Motile Aeromonas Septicemia. Ec Veterinary Science. 4(7): 498-510.

Anyanwu M.U, K.F Chah, and VS. Shoyinka, 2015. Evaluation of pathogenicity of motile Aeromonas species in African catfish. Internatinal Journal of Fisheries and Aquatic Studies. 2 (3) : $93-98$.

Ardy, F.M., Desrina dan A.H.C. Haditomo. 2019. Penambahan Kandidat Probiotik Bacillus methylothrophicus Secara Berkala pada Media Pemeliharaan Untuk Pencegahan Infeksi Bakteri Aeromonas hydrophila pada Ikan Nila (Oreochromis niloticus). Jurnal Sains Akuakultur $\begin{array}{lll}\text { Tropis. } & 3(2): & 50-59\end{array}$ DOI: https://doi.org/10.14710/sat.v3i2.4069

Asniatih, M. Idris dan K. Sabilu. 2013. Studi Histopatologi Ikan Lele Dumbo (Clarias gariepinus) yang Terinfeksi Bakteri Aeromonas hydrophila. Jurnal Mina Laut Indonesia. 3(12): 13-21.

Badan Standardisasi Nasional. 2014. Ikan Lele Dumbo (Clarias sp.) Bagian 4: Produksi Benih. SNI 6484.4:2014.

Basyuni, M., P.Y.A.B. Ginting dan I. Lesmana. 2017. Phytochemical Analysis of Binahong (Anredera cordifolia) Leaves Extract to Inhibit In Vitro Growth of Aeromonas hydrophila. Proceedings of the $3^{\text {rd }}$ International Symposium on Allied Chemistry pp : 223 -231. https://doi.org/10.1063/1.5011929

Chandrarathna, H.P.S.U., C. Nikapitiya, S.H.S. Dananjaya, C.U.B. Wijerathne, S.H.M.P. Wimalasena, H.J. Kwun, G.J. Heo, J. Lee, dan M.D. Zoysa. 2018 Outcome of Co-infection with Opportunistic and Multidrug Resistant Aeromonas hydrophila and $A$. veronii in Zebrafish: Identification, Characterization,

(C) Copyright by Saintek Perikanan: Indonesian Journal of Fisheries Science and Technology, ISSN : 1858-4748 
Pathogenicity and Immune Responses. Fish and Shellfish Immunology. 80: 573-581. https://doi.org/10.1016/j.fsi.2018.06.049Get

Dadiono, M. S., S. Andayani dan K. Zailanie. 2017. The Effect of Different Dosage of Anredera cordifolia (Ten.) Steenis Leaves Extract towards the Survival Rate of African Catfish (Clarias sp.) Infected by Aeromonas salmonicida. International Journal of ChemTech Research,10(4): 669-673.

Dageubun, J.L. dan J. Metungun. 2017. Hematology of Vibrio alginolyticus Infected Humpback Grouper Cromileptes altivelis, Under Treatment of Alstonia acuminate Shoot Extract. AACL Bioflux. 10(2): 274284. http://www.bioflux.com.ro/docs/2017.274284.pdf

Hardi, E.H., I.W. Kusuma, W. Sueinarti, G. Saptiani, Sumoharjo dan A.M. Lusiastuti. 2017. Utilization of Several Herbal Plant Extracts on Nile Tilapia in Preventing Aeromonas hydrophila and Pseudomonas sp. Bacterial Infection. Nusantara Bioscience. 9(2): 220-228

DOI https://doi.org/10.13057/nusbiosci/n090219

Hardi, E.H., G. Saptiani, I.W. Kusuma, W. Suwinarti dan A. Sudaryono. 2018 a Inhibition of Fish Bacteria Pathogen in Tilapia Using a Concoction Three of Borneo Plant Extracts. IOP Conference Series: Earth and Environmental Science. 144: 1-8. https://doi.org/10.1088/1755-1315/144/1/012015

Hardi, E.H., R.A. Nugroho, G. Saptiani, R. Sabrinah, M. Agriandini dan M. Mawardi. 2018 ${ }^{\text {b. Identification of }}$ Potentially Pathogenic Bacteria from Tilapia (Oreochromis niloticus) and Channel Catfish (Clarias batracus) Culture in Samarinda, East Kalimantan, Indonesia. Biodiversitas. 19(2): 480-488. DOI https://doi.org/10.13057/biodiv/d190215

Haresmita, P.P. DS. Sakti, N. Yuniarti dan S. Wahyuono. 2019. Phagocytosis Activity of Binahong ,Anredera cordifolia, (Ten.) Steenis from Secang, Magelang, Central Java, Indonesia. Jurnal Farmasi Sains dan Komunitas. $\quad 16(1)$ : 7-13. doi: http://dx.doi.org/10.24071/jpsc.001693

KKP, 2018. https://kkp.go.id/djpb/artikel/3042-capaiankinerja-subsektor-perikanan-budidaya-dan outlooktahun-2018

Kusdarwati, R., Rozi., D. Dinda dan I. Nurjanah. 2018. Antimicrobial Resistance Prevalence of Aeromonas hydrophila Isolates from Motile Aeromonas septicemia Disease. IOP Conf. Series: Earth and Environmental Science, 137: 1-5. https://doi.org/10.1088/1755-1315/137/1/012076

Lusiastuti, A.M. dan E.H. Hardi. 2018. Gambaran Darah sebagai Indikator Kesehatan pada Ikan Air Tawar. Prosiding Seminar Ikan VI. 65-69.

Mawardi, M., A.M. Lusiatuti dan D.F. Idealistina. 2019. Curcuma xanthorrhiza Roxb.: Control Gyrodactyliasis in Catfish Clarias gariepinus. International Journal of Fisheries and Aquatic Studies. 7(6): 197-202.

Miladiyah, I. dan B.R. Prabowo. 2012. Ethanolic Extract of Anredera cordifolia (Ten.) Steenis Leaves Improved Wound Healing in Guinea Pigs. Universa Medicina. 31(1):

4-11.
DOI: http://dx.doi.org/10.18051/UnivMed.2012.v31.4 $-11$

Muslikha, S. Pujiyanto, S.N. Jannah dan H. Novita. 2016. Isolasi, Karakterisasi Aeromonas hydrophila dan Deteksi Gen Penyebab Penyakit Motile Aeromonas Septicemia (MAS) dengan 16S rRNA dan Aerolysin pada Ikan Lele (Clarias sp.). Jurnal Biologi. 5(4): 1-7.

Naibaho, F.F., D. Suryanto dan R. Leidonald. 2018. Jenis-Jenis Bakteri Potensial Patogen pada Ikan Patin (Pangasius sp.) di Kolam Budidaya Ikan Air tawar Kota Beling Tanah Air Kecamatan Tanjung Anom Provinsi Sumatera Utara. Aquacoastmarine. 6(1): 1-11.

Putra, G.P., Mulyana dan F.S. Mumpuni. 2015. Pengaruh Pemberian Ekstrak Temulawak (Curcuma xanthoriza Roxb) Terhadap Mortalitas dan Gambaran Darah Benih Ikan Nilem (Osteochilus hasselti) dengan Uji Tantang Menggunakan Bakteri Aeromonas hydrophila. Jurnal Mina Sains. 1(2): 67-78. DOI: http://dx.doi.org/10.30997/jms.v1i2.12

Rahmaningsih, S., M. Zaenuddin dan A. Sudianto. 2018. Gambaran Hematokrit Darah Ikan Lele Sangkuriang (Clarias gariepinus) yang Diberi Pakan Serbuk Daun Majapahit (Cresentia cujete L.) dan Diinfeksi dengan Bakteri Aeromonas hydrophila. Jurnal Kelautan dan Perikanan Terapan. 1(2): 6367.http://dx.doi.org/10.15578/jkpt.v1 i2.7334

Riauwaty, M., W. Windarti, T.E. Y. Sari dan A. Adelina. 2019. Blood Condition of Pangasius hypophthalamus Fed with Tumeric Enriched Pellets and Infected with Aeromonas hydrophila. IOP Conference Series: Earth and Environmental Science. 348: 1-6. https://doi.org/10.1088/1755-1315/430/1/012025

Rosidah, A. Rizal, I. Rustikawati dan F. Octavia. 2018. The Effect of Differences in Altitude Location of an Aquaculture on Fish's Hematocrit and Fish's Haemoglobin of Carp Fish and Resistance to Bacterial Attack. IOP Conference Series: Earth and Environmental $\quad$ Science. 137: 1-9 https://doi.org/10.1088/1755-1315/137/1/012008

Rosmawaty, R., Rosidah dan E. Liviawaty. 2016. Pemanfaatan Ekstrak Kulit Jengkol dalam Pakan Ikan Untuk Meningkatkan Imunitas Benih Gurame (Osphronemus gouramy) Terhadap Infeksi Bakteri Aeromonas hydrophila. Jurnal Perikanan dan Kelautan. 7(1): 1422.

Rustikawati, I. 2011. Peningkatan imunitas Ikan Nila (Oreochromis niloticus) terhadap Serangan Streptococciasis Menggunakan Ekstrak Sargassum sp. Indonesian Journal of Apllied Scieces. 1(1): 18-30. https://doi.org/10.24198/.v1i1.1807.g9587

Saparuddin. 2018. Pengaruh Ekstrak Etanol Terhadap Peningkatan Konsentrasi Hemoglobin dan Nilai Hematokrit Ikan Kerapu Tikus. Jurnal Saintifik. 4(1): 39-46.

DOI: https://doi.org/10.31605/saintifik.v4i1.142

Sari, N.S., I. Lukistyowati dan N. Aryani. 2012. Pengaruh Pemberian Temulawak (Curcuma xanthorriza Roxb) Terhadap Kelulushidupan Ikan Mas (Cyprinus carpio L) Setelah Diinfeksi Aeromonas hydrophila. Jurnal Perikanan dan Kelautan. 17(2): 43-59.

\footnotetext{
C Copyright by Saintek Perikanan: Indonesian Journal of Fisheries Science and Technology, ISSN : 1858-4748
} 
Sarjito, 2010. Aplikasi Biomolekuler dalam Karakterisasi Agensia Penyebab Penyakit Vibrio dan Potensi Bakteri Sponge Sebagai Pengendali Vibriosisi Pada Ikan Kerapu Program Doktor Manajemen Sumberdaya Pantai, Fakultas Pasca Sarjana Universitas Diponegoro.

Sarjito., A. H. C. Haditomo., R. W. Ariyati., A. Sabdaningsih., Desrina dan S. B. Prayitno. 2019. Screening of potential isolate candidates probiotic against Aeromonas hydrophila from Boyolali, Indonesia. IOP Conf. Series: Journal of Physics: Conf. Series 1217: 17. https://doi.org/10.1088/1742-6596/1217/1/012147

Setiyowati, I., H. Suprapto, dan G. Mahasri. 2019. The Effects of Mercury Chloride $(\mathrm{HgCl} 2)$ on the Change in Hematology and Blood Sugar Level in Carp (Cyprinus carpio. IOP Conference Series: Earth and Environmental Science. 236: 1-11. https://doi.org/10.1088/1755-1315/236/1/012104

Susanti dan F. Bachmid. 2016. Perbandingan Metode Ekstraksi Maserasi dan Refluks Terhadap Kadar Fenolik dari
Ekstrak Tongkol Jagung (Zea mays L.). Konversi. (2): 87-93. DOI https://doi.org/10.24853/konversi.5.2.87-92

Tiamiyu, A.M., Olatoye, I.O. dan Addeji O.B. 2019. Blood Indices of African Catfish (Clarias gariepinus) Following Dietary Administration of Talinum triangulare. Internastional Journal of Research Granthaalayah. 7(4): 185-198. DOI: 10.5281 /zenodo. 2653843

Wahjuningrum, D., R. Astrini dan M. Setiawati. 2013. Pencegahan Aeromonas hydrophila pada Benih Ikan Lele menggunakan Bawang Putih dan Meniran. Jurnal Akuakultur Indonesia. 12(1): 86-94.

Wulansari, F., S.B. Prayitno, dan A.H.C. Haditomo. 2019. Study of Probiotic Candidate CBL20 for Inhibiting of Aeromonas hydrophila With Different Concertration in Tilapia (Oreochromis niloticus). IOP Conference Series: Earth and Environmental Science. 246: 1-8. https://doi.org/10.1088/1755-1315/246/1/012032. 